\title{
Clinical Toxoplasmosis in Dogs and Cats: An Update
}

\author{
Rafael Calero-Bernal ${ }^{1 *}$ and Solange M. Gennari ${ }^{2,3}$ \\ ${ }^{1}$ Saluvet Group, Department of Animal Health, Complutense University of Madrid, Madrid, Spain, ${ }^{2}$ Program of Master's in \\ Animal Medicine and Welfare, Faculty of Veterinary Medicine, University of Santo Amaro, São Paulo, Brazil, ${ }^{3}$ Faculty of \\ Veterinary Medicine, University of São Paulo, São Paulo, Brazil
}

Toxoplasmosis is caused by the globally distributed protozoan parasite Toxoplasma gondii (phylum Apicomplexa); the disease can be clinically important for almost all homeothermic animals, including birds and humans. Toxoplasmosis course involves general clinical signs, such as fever, anorexia, or dyspnea, and more specific signs with neural, respiratory, cutaneous, or ocular involvement. Because of the wide range of clinical signs, the diagnosis in domestic and pet animals can be complicated. Hence, this review aims to provide a comprehensive analysis of some scarcely discussed aspects of toxoplasmosis, such as ocular and cutaneous manifestations, congenital infections, influence of $T$. gondii genotype on clinical toxoplasmosis, and recent findings regarding differential diagnosis. This review could be of special interest to clinicians and researchers.

\section{OPEN ACCESS}

Edited by:

Luís Pita Gondim,

Federal University of Bahia, Brazil

Reviewed by:

Quan Liu,

Foshan University, China

Si-Yang Huang,

Yangzhou University, China

*Correspondence:

Rafael Calero-Bernal

r.calero@ucm.es

Specialty section: This article was submitted to

Parasitology,

a section of the journal Frontiers in Veterinary Science

Received: 29 October 2018 Accepted: 07 February 2019 Published: 26 February 2019

Citation:

Calero-Bernal R and Gennari SM (2019) Clinical Toxoplasmosis in Dogs and Cats: An Update. Front. Vet. Sci. 6:54. doi: 10.3389/fvets.2019.00054
Keywords: Toxoplasma gondii, dogs, cats, clinical disease, symptoms, genotype, differential diagnosis

\section{INTRODUCTION}

Toxoplasmosis is caused by the globally distributed intracellular protozoan parasite Toxoplasma gondii (phylum Apicomplexa, family Sarcocystidae). The disease has a complex epidemiology; the parasite is capable of infecting virtually all warm-blooded animals, and has a two-host life cycle (1). Domestic cats and other felids are the definitive hosts (DHs). All non-feline animals, including dogs and humans, are intermediate hosts (IHs), however, T. gondii can also undergo asexual reproduction in Felidae that act as IHs. There are three stages in the protozoan's life cycle that explain its biological success. First, tachyzoites multiply actively in tissues, quickly spread to almost all organs, and cause most of the pathology. Once they reach specific tissues (central nervous system, muscle, and viscera), they convert into bradyzoites which remain latent in a cyst form leading to a life-long chronic infection until a $\mathrm{DH}$ ingests the tissue. Then, bradyzoites are released and penetrate the small intestine epithelial cells, giving rise to schizonts that form gamonts and, finally, oocysts. Oocysts constitute the environmentally resistant (and infective) stage. Hosts can become infected horizontally by ingesting tissues containing cysts, consuming water or food contaminated with oocysts, or by transfusion or transplantation with parasitized organs. They can also result infected vertically, by congenital infection.

In general, $T$. gondii infection is associated with a low rate of morbidity and mortality in dogs and cats, but clinical consequences for primary care clinics should be taken into account. Clinical toxoplasmosis is more frequent in cats than in dogs, which commonly suffer from neosporosis by Neospora caninum, and among them, non-vaccinated animals are more susceptible.

On review of the available literature (www.ncbi.nlm.nih.gov), $\sim 79$ clinical cases in cats and 45 in dogs have been comprehensively reported after 1989, when $N$. caninum was newly described causing toxoplasmosis-like disease in dogs (1). Numerous studies have shown seroprevalence and/or parasite prevalence ranges in dogs and cats from 6 to $88 \%$ worldwide [reviewed in reference 
(1)]. Seroprevalence status in cats is essential regarding zoonosis prevention and has been recently reviewed elsewhere (2).

Other review papers have focused on toxoplasmosis diagnosis and treatment. In the present article, the authors aimed to highlight less known clinical manifestations, to review aspects regarding differential diagnosis, and to determine how strain/genotype may be involved in the clinical presentation of the disease, which could be of special interest for clinicians and researchers.

\section{CLINICAL PRESENTATION AND PATHOLOGY OF TOXOPLASMOSIS IN DOGS AND CATS}

Clinical cases of toxoplasmosis are much more frequent in cats than in dogs $(1,3)$, which mostly suffer from neosporosis (4). A high proportion of $T$. gondii clinical infections are triggered by immunosuppressive chemotherapy (5). Cases of co-infections that can aggravate a process by $T$. gondii $(6,7)$ are discussed in the respective section of the present paper.

Dogs rarely suffer from toxoplasmosis as a primary disease, and, in most cases, the disease is linked to immunosuppression and absence of vaccination against canine distemper virus (CDV). Neurological disease, with signs of seizures, cranial nerve deficits, tremors, ataxia, and paresis or paralysis within encephalomyelitis (8), may be seen. Paraparesis and tetraparesis that progressed to lower motor neuron paralysis and nodules in the spinal cord, were described in a dog with dual infection with Sarcocystis neurona and T. gondii (6). Other reported cases of toxoplasmosis in dogs include: noise sensitivity in an 8-year-old female collie (9); myositis that initially showed an abnormal gait, muscle wasting, and stiffness (10); and ocular disease described as necrotizing conjunctivitis (11), anterior uveitis, endophthalmitis, and chorioretinitis (12).

Cutaneous manifestations are generally associated with immunosuppression after corticoid therapy and transplantation (13-17). Lesions are characterized by erythematous epidermal nodules, pyogranulomatous and necrotizing dermatitis, and panniculitis, with multifocal vasculitis and vascular thrombosis. Zoites are frequently found in lesions. In general, clindamycin is the treatment of choice for cutaneous toxoplasmosis (14), although $N$. caninum is the most frequent coccidian causing skin lesions in dogs, what should be considered in a differential diagnosis (4).

In cats, clinical toxoplasmosis is more severe in transplacentally infected kittens (18), which frequently develop hepatitis or cholangiohepatitis, pneumonia, and encephalitis and show signs of ascites, lethargy, and dyspnea. In adults, unspecific clinical signs can be observed $(19,20)$. The occurrence of hepatitis and abdominal involvement, hepatic failure, and hyperplastic cholangitis has been described yet $(21,22)$. In addition, extra-intestinal enteritis (21), inflammatory intestinal disease (23), thickening of the gastric wall due to eosinophilic fibrosing gastritis, and regional lymphadenopathy $(21,24)$ were noted. The disease may be rapidly fatal in cats with severe respiratory or neurological signs (18).
Pneumonia is the main sign of generalized toxoplasmosis (25), and acute respiratory distress syndrome and septic shock may occur (26). Ocular toxoplasmosis has been observed in cats without poly-systemic clinical signs of disease, and anterior or posterior uveitis, iritis, iridocyclitis, or chorioretinitis. Aqueous flare, keratic precipitate, lens luxation, glaucoma, and retinal detachment are common manifestations of uveitis (19). Therefore, ocular fundic examination should be a routine part of the examination in febrile cats (1). Less frequent findings, such as myocarditis with echocardiographic changes (27), diarrhea with oocysts (28), or pyogranulomatous cystitis after renal transplantation (29), were also reported. Primary or reactive neurological disease is frequent in cats; infection of the encephalon (30), spinal cord, and nerves has been identified (3133). In general, myelitis, marked generalized mononuclear cell inflammation of the gray matter, non-suppurative encephalitis, and perivascular cuffing are common findings. Cases of intracranial granuloma $(34,35)$ and panencephalitis (36) have been also addressed.

Generalized toxoplasmosis in immunocompetent and immunosuppressed cats, involving acute interstitial pneumonia, acute and multifocal necrotizing hepatitis, non-suppurative meningoencephalitis with glial granuloma, moderate lymphadenomegaly, and splenomegaly, have been reported (37-40). In addition, cutaneous manifestations with nodules that may ulcerate are sometimes related to feline immunosuppression (40-42).

\section{CONGENITAL INFECTIONS IN DOGS AND CATS}

Most of infections in dogs and cats occur horizontally, but infectivity by the oral route depends on the parasite stage ingested, this issue has been revised thoroughly elsewhere (1). By contrast, the aspect of congenital infections in dogs and cats has not been reviewed in depth in the literature. After primo-infection during pregnancy, parasitemia can cause placentitis, followed by spread of tachyzoites to the fetus. Little is known about transplacental toxoplasmosis in dogs, although its occurrence is thought to be less common than in other species (1). The only evidence is based on two studies $(43,44)$ that reported a high prevalence of $T$. gondii DNA detection in fetal tissues of dogs, but the significance of these findings is unknown.

In dogs, T. gondii was isolated from pups from a seropositive bitch in Australia; however, no clinical signs were seen in any of the animals (45) (Table 1). T. gondii DNA was detected in fresh semen from five out of eleven seropositive naturally infected healthy dogs in Brazil, and in vitro isolation of the parasite was achieved (50). However, venereal transmission had been demonstrated earlier, when fresh semen, collected from experimentally infected dogs that tested positive for T. gondii, was used for artificial insemination (AI) of four naïve bitches. Seroconversion was observed in all females seven days after AI, and reabsorption occurred in two of the dogs. The remaining bitches sustained full-term gestations, and T. gondii cysts were detected in brains of four offspring (51). 


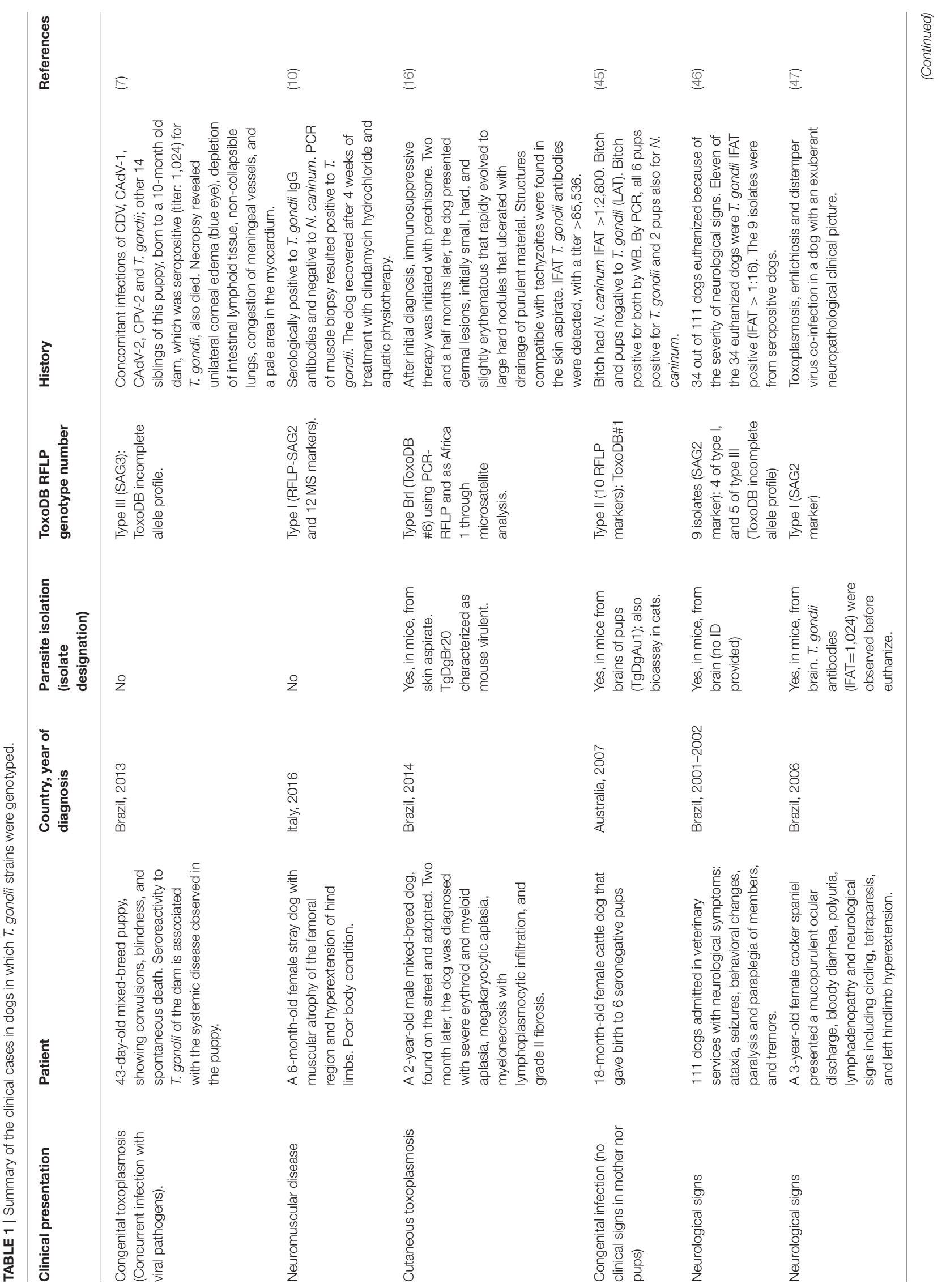




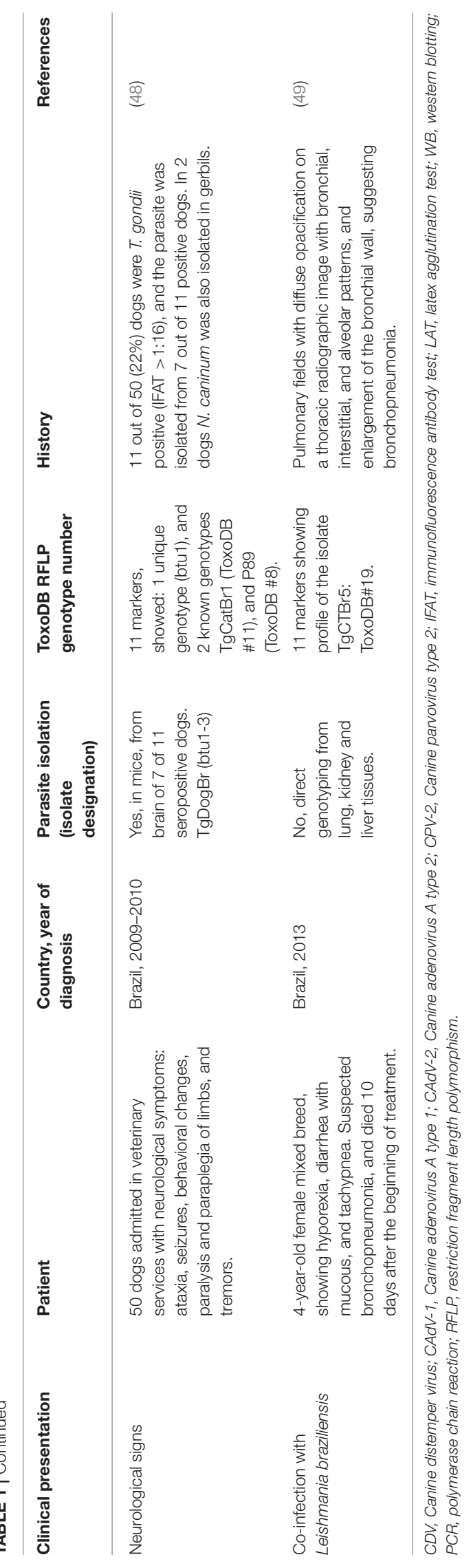

Before 2010, scientists were not aware of any confirmed report of natural congenital toxoplasmosis in dogs (1), but there was experimental evidence for it. It was confirmed when three bitches were fed 15,000 sporulated T. gondii oocysts at 32,40 , and 56 days of gestation, and two of the three dogs infected during pregnancy showed evidence of congenital infection, while one aborted (52). Further studies also showed transplacental transmission with miscarriage and fetal death in naturally infected bitches challenged with subcutaneous and oral administration of tachyzoites and oocysts, respectively (53).

On the other hand, kittens born to queens infected with $T$. gondii during gestation can become infected transplacentally or via suckling (54); in general, clinical illness is common and severity varies with the stage of gestation at the time of infection (1). Congenital toxoplasmosis was diagnosed histologically in nine kittens and one queen from five litters. The queen died of generalized toxoplasmosis, and the kittens presented with toxoplasmic hepatitis and pneumonia; in addition, three 1-month-old kittens from another litter were shedding $T$. gondii-like oocysts (18). After oral inoculation of five fullterm pregnant queens with T. gondii tissue cysts, the clinical signs and lesions were comprehensively described in a pioneer study (54); twenty-two live and three dead kittens were born 16 to 31 days after inoculation. A wide range of histologic lesions included: proliferative interstitial pneumonia, necrotizing hepatitis, myocarditis, skeletal and glossal myositis, nonsuppurative encephalitis affecting the cerebrum, brain stem, and spinal cord, uveitis, necrotizing adrenal adenitis, and interstitial nephritis. Also, placental lesions consisting of grossly visible areas of necrosis and mineralization were observed.

Recent articles reporting on congenital infection in cats are scarce. In Turkey, an interesting case of fatal systemic toxoplasmosis with necrotic pneumonia involving a 2.5 -year-old pregnant queen and its kitten was reported (55).

Experimental infection of queens in the middle third of pregnancy, using two different Brazilian isolates (BrI, BrIII), showed almost no difference in abortion and premature stillbirth rates (56). Venereal transmission in cats does not appear to occur; T. gondii was not detected in the semen, testicles, or epididymis tissues of primo-infected cats, after challenging with $T$. gondii tissue cysts and tachyzoites (57). Infection through milk ingestion in cats is supported by results, such as the detection of $T$. gondii by bioassay and PCR in milk of nursing queens after experimental infection (58). Cats of any age may die or develop severe disease following parenteral inoculation with tachyzoites, bradyzoites, or oocysts, and large doses of corticosteroids can aggravate clinical toxoplasmosis (1). Cats infected during pregnancy can develop placentitis, and congenitally infected kittens, severe toxoplasmosis, including ophthalmitis $(54,59-61)$.

\section{IMMUNOSUPRESSION AND CLINICAL TOXOPLASMOSIS}

Vast literature has been published since initial studies $(1,3,62)$ exposed that viral infections in dogs and cats may predispose to clinical toxoplasmosis; however, the results are not conclusive. A 
few cases of feline clinical toxoplasmosis combined with feline immunodeficiency virus (FIV) (63) and feline leukemia virus (FeLV) (40) have been described. During experimental infections, challenge with FIV triggered the disease and predisposed cats to acute generalized toxoplasmosis (64), but later studies on the general population did not identify the same association (65).

Organ transplantation has been identified as a cause of acute toxoplasmosis; three cats and one dog developed signs 3-6 weeks after renal transplantation (13). Furthermore, pyogranulomatous cystitis was observed in a cat 6 weeks after the same surgery (29). All animals had received immunosuppressive therapy. Therefore, consideration should be given to determining the serological status against $T$. gondii prior to use drugs that are potent inhibitors of cell-mediated immunity, such as cyclosporine. It has been reported in the literature that skin nodules worsened after treatment with corticosteroids in two cats $(41,66)$, and three cases of generalized toxoplasmosis with pneumonia in cats were observed after cyclosporine $(5,67)$ and prednisolone (68) treatments. In another case, disseminated toxoplasmosis involving acute respiratory distress syndrome and septic shock occurred in a cat (26) after the use of cyclosporine for eosinophilic dermatitis treatment. Several dogs developed cutaneous toxoplasmosis after treatment with prednisone and cyclosporine against immune-mediated thrombocytopenia and immune-mediated hemolytic anemia $(14,16,17,69)$. Moreover, topical antiinflammatory therapy required to control keratoconjunctivitis sicca in a dog triggered a necrotizing conjunctivitis by T. gondii (11).

The re-shedding of oocysts by cats remains an important aspect in the epidemiology of T. gondii. It was previously believed that, after the first infection, cats would excrete thousands of oocysts, and then elimination would no longer occur during the life of the animal. However, recent studies have demonstrated reshedding after experimental application of immunosuppressive therapy (70). In addition, it was reported that clinically ill cats can shed oocysts (28), suggesting that special precautions must be taken during clinical care. Besides, cats that were experimentally re-infected with $T$. gondii at 12,24 , and 36 months after the primary infection, re-excreted oocysts and the amount was higher the longer the time after the primary infection, especially when a heterologous strain was used (71).

\section{TOXOPLASMA GONDII GENOTYPE AND CLINICAL TOXOPLASMOSIS}

One recurrent question is how the $T$. gondii strain (genotype, http://toxodb.org/toxo/) relates to the occurrence of clinical disease. This concept is still under study. In a recent paper carried out in Australia (20), the authors compared the genotypes of $T$. gondii in latently infected cats with those in cats suffering from clinical toxoplasmosis, by direct genotyping of the DNA isolated from tissue samples. ToxoDB genotype \#3 was commonly found among both sample sets, suggesting that the $T$. gondii genotype is not a determinant of clinical disease in naturally infected cats in Australia.
The current knowledge regarding $T$. gondii strain/genotype distribution in clinical cases of dogs and cats is summarized in Tables 1,2, respectively. Only ToxoDB\#3 has been detected in five feline clinical cases from two different countries, Australia (20) and Switzerland (37); therefore, no specific genotype can be associated with a certain clinical outcome or presentation. Thus, whether disease depends on immunological status, infection dose, co-infection rates, and geographical location (understood as genetic variant distribution), rather than on "specific genotype" involvement, is still under debate. It can be concluded that there is no specific cluster of strains associated with clinical toxoplasmosis; hence, further studies based on isolation and strain genotyping will be of major interest, especially in locations where a wide range of $T$. gondii genotypes have been described in animals and humans.

On the top of that, there is a wide genetic diversity within the parasites isolated from asymptomatic dogs $(73,74)$ and cats $(72,75)$, corresponding to a complex epidemiology shown in different geographical areas [(76), http://toxodb.org/toxo/].

\section{RECENT FINDINGS REGARDING DIFFERENTIAL DIAGNOSIS}

When congenital, cutaneous, generalized (pneumonia, myositis, etc.), or neurological toxoplasmosis-like clinical signs are identified in dogs and cats, clinicians and researchers should suspect of protozoal infections, caused by Apicomplexans (4, 77, 78). As mentioned before, clinical cases are frequently associated with immunosuppressive treatments $(20,79,80)$. Differential diagnosis might be influenced by the geographical location where the clinical cases occur; for example, S. neurona causing encephalitis and Sarcocystis canis causing hepatitis have been confined to the Americas (78).

Reports of clinical protozoal infections resembling toxoplasmosis have been published, including cutaneous neosporosis in a dog (81); a cutaneous infection by a $T$. gondii-like parasite in a dog and a cat $(42,82,83)$; congenital infections in dogs by S. neurona (84) and N. caninum (85); generalized disease showing pneumonia in dogs by Sarcocystis spp. (86), N. caninum (85), and lungworms (87); hepatitis in dogs by Sarcocystis spp. (88), S. canis (77), Sarcocystis caninum, Sarcocystis svanai (89), and N. caninum (79); myocarditis in dogs by the West Nile Virus (90) and N. caninum (91); and skeletal muscle myositis in dogs by S. caninum and S. svanai $(89,92)$. Also, non-infectious neurological diseases showing a wide range of signs are frequent in cats $(30,93)$ and dogs $(94,95)$. In dogs, $\mathrm{CDV}$ is an important cause of neurological disease, but other infectious agents include eastern equine encephalitis virus (96), S. neurona (97), and N. caninum $(8,85)$. Co-infections of $T$. gondii with viruses, like CDV, canine adenovirus type 1 and type 2 , and canine parvovirus type $2(7,72)$, along with rickettsial bacteria (47) and protozoans, like Leishmania spp., N. caninum, and $S$. neurona $(6,15,49,98-100)$, can mask the infections, so clinicians need to pay attention to all variables.

As an instance of cutaneous toxoplasmosis was described in an immunosuppressed dog. The material collected from the 

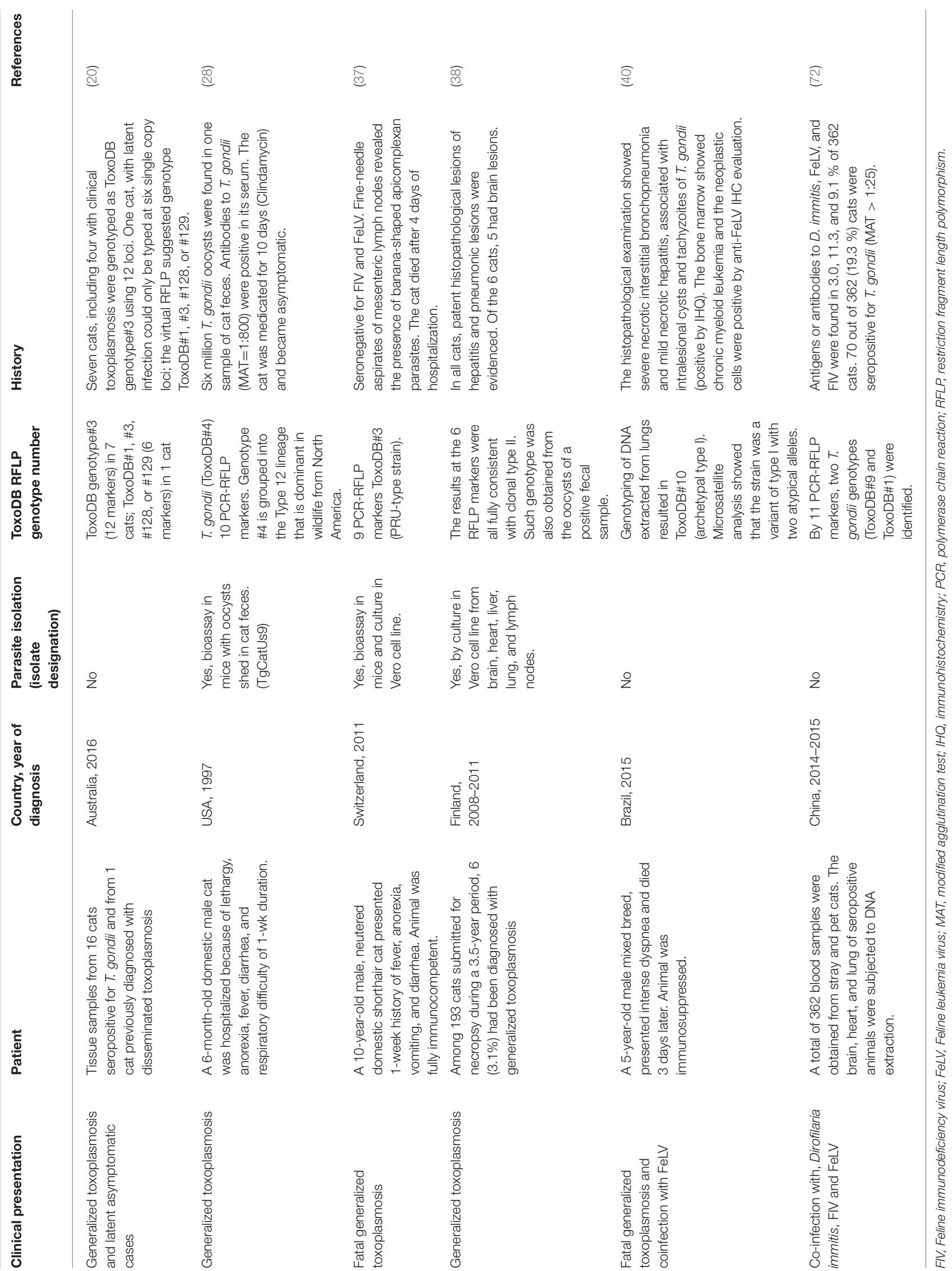
skin lesions was negative for fungal and bacterial cultures, and tachyzoites were found on the Giemsa-stained smears. Serum was tested for N. caninum, T. gondii, Leishmania infantum chagasi, and Leishmania amazonensis IgG antibodies, and only $T$. gondii antibodies were detected (IFAT titer=65,536). DNA was extracted from the collected material and examined by nested PCR, confirming the diagnosis of T. gondii (16) (Table 1).

\section{CONCLUSION}

Clinical toxoplasmosis in dogs and cats has a wide range of presentations, ranging from general symptoms like fever and dyspnea to more specific signs involving neural, respiratory, cutaneous and ocular signs, thus a comprehensive differential diagnosis with leishmaniosis, neosporosis, and sarcocystosis constitute a key element. Because clinical disease is frequently associated with immunosuppressive therapy, an special interest should be paid to the serological status of $T$. gondii

\section{REFERENCES}

1. Dubey JP. Toxoplasmosis of Animals and Humans. 2nd ed. Boca Raton, FL: CRC Press (2010)

2. Baneth G, Thamsborg SM, Otranto D, Guillot J, Blaga R, Deplazes P, et al. Major parasitic zoonoses associated with dogs and cats in Europe. J Comp Pathol. (2016) 155:S54-74. doi: 10.1016/j.jcpa.2015.10.179

3. Dubey JP, Lindsay DS, Lappin MR. Toxoplasmosis and other intestinal coccidial infections in cats and dogs. Vet Clin North Am Small Anim Pract. (2009) 39:1009-34. doi: 10.1016/j.cvsm.2009.08.001

4. Dubey JP, Hemphill A, Calero-Bernal R, Schares G. Neosporosis in Animals. Boca Raton, FL: CRC Press (2017). doi: 10.1201/9781315152561

5. Barrs VR, Martin P, Beatty JA. Antemortem diagnosis and treatment of toxoplasmosis in two cats on cyclosporin therapy. Aust Vet J. (2006) 84:30-5. doi: 10.1111/j.1751-0813.2006.tb13119.x

6. Gerhold R, Newman SJ, Grunenwald CM, Crews A, Hodshon A, Su C. Acute onset of encephalomyelitis with atypical lesions associated with dual infection of Sarcocystis neurona and Toxoplasma gondii in a dog. Vet Parasitol. (2014) 205:697-701. doi: 10.1016/j.vetpar.2014.09.008

7. Headley SA, Alfieri AA, Fritzen JT, Garcia JL, Weissenböck H, da Silva $\mathrm{AP}$, et al. Concomitant canine distemper, infectious canine hepatitis, canine parvoviral enteritis, canine infectious tracheobronchitis, and toxoplasmosis in a puppy. J Vet Diagn Invest. (2013) 25:129-35. doi: $10.1177 / 1040638712471344$

8. Patitucci AN, Alley MR, Jones BR, Charleston WAG. Protozoa1 encephalomyelitis of dogs involving Neosporum caninum and Toxoplasma gondii in New Zealand. N Z Vet J. (1997) 45:231-5. doi: 10.1080/00480169.1997.36035

9. Papini R, Mancianti F, Saccardi E. Noise sensitivity in a dog with toxoplasmosis. Vet Rec.(2009) 165:62. doi: 10.1136/vetrec.165.2.62-b

10. Migliore S, La Marca S, Stabile C, Di Marco Lo Presti V, Vitale M. A rare case of acute toxoplasmosis in a stray dog due to infection of $T$. gondii clonal type I: public health concern in urban settings with stray animals? BMC Vet Res. (2017) 13:249. doi: 10.1186/s12917-017-1176-3

11. Swinger RL, Schmidt KA Jr, Dubielzig RR. Keratoconjunctivitis associated with Toxoplasma gondii in a dog. Vet Ophthalmol. (2009) 12:56-60. doi: 10.1111/j.1463-5224.2009.00675.x

12. Wolfer J, Grahn B. Diagnostic ophtalmology. case report of anterior uveitis and endophtalmitis. Can Vet J. (1996) 37:506-7.

13. Bernsteen L, Gregory CR, Aronson LR, Lirtzman RA, Brummer DG. Acute toxoplasmosis following renal transplantation in three cats and a dog. $\mathrm{J} \mathrm{Am}$ Vet Med Assoc. (1999) 215:1123-6. antibodies when corticosteroid drugs or transplant surgery are prescribed. In addition, there is a lack of knowledge regarding clinical consequences driven by venereal and congenital transmission. Finally, further studies aiming the isolation of T. gondii from clinical cases is of major interest to establish a possible association of strains causing specific clinical diseases and outcomes.

\section{AUTHOR CONTRIBUTIONS}

RC-B and SMG equally contributed with the acquisition and analysis of data, drafting, and critical revision of the manuscript.

\section{FUNDING}

RC-B is funded by the postdoctoral grants of the Complutense University of Madrid (ref. CT65/16). SMG is in receipt of a fellowship from CNPq (Brazil).
14. Hoffmann AR, Cadieu J, Kiupel M, Lim A, Bolin SR, Mansell J. Cutaneous toxoplasmosis in two dogs. J Vet Diagn Invest. (2012) 24:636-40. doi: $10.1177 / 1040638712440995$

15. Oliveira VDC, Boechat VC, Mendes Junior AAV, Madeira MF, Ferreira LC, Figueiredo FB, et al. Occurrence of Leishmania infantum in the central nervous system of naturally infected dogs: parasite load, viability, co-infections and histological alterations. PLoS ONE. (2017) 12:e0175588. doi: 10.1371/journal.pone.0175588

16. Pena HF, Moroz LR, Sozigan RK, Ajzenberg D, Carvalho FR, Mota CM, et al. Isolation and biological and molecular characterization of Toxoplasma gondii from canine cutaneous toxoplasmosis in Brazil. J Clin Microbiol. (2014) 52:4419-20. doi: 10.1128/JCM.02001-14

17. Webb JA, Keller SL, Southorn EP, Armstrong J, Allen DG, Peregrine AS, et al. Cutaneous manifestations of disseminated toxoplasmosis in an immunosuppressed dog. J Am Anim Hosp Assoc. (2005) 41:198-202. doi: $10.5326 / 0410198$

18. Dubey JP, Carpenter JL. Neonatal toxoplasmosis in littermate cats. J Am Vet Med Assoc. (1993) 203:1546-9.

19. Dubey JP, Carpenter JL. Histologically confirmed clinical toxoplasmosis in cats: 100 cases (1952-1990). J Am Vet Med Assoc. (1993) 203:1556-66. PMid:8288479.

20. Brennan A, Donahoe SL, Beatty JA, Belov K, Lindsay S, Briscoe KA, et al. Comparison of genotypes of Toxoplasma gondii in domestic cats from Australia with latent infection or clinical toxoplasmosis. Vet Parasitol. (2016) 228:13-6. doi: 10.1016/j.vetpar.2016.06.008

21. Cohen TM, Blois S, Vince AR. Fatal extraintestinal toxoplasmosis in a young male cat with enlarged mesenteric lymph nodes. Can Vet J. (2016) 57:483-6.

22. De Tommasi AS, Morini M, Turba ME, Otranto D, Bettini G. Hyperplastic cholangitis in a naturally Toxoplasma gondii-infected cat. Vet Q. (2014) 34:229-31. doi: 10.1080/01652176.2014.978510

23. Peterson JL, Willard MD, Lees GE, Lappin MR, Dieringer T, Floyd E. Toxoplasmosis in two cats with inflammatory intestinal disease. J Am Vet Med Assoc. (1991) 99:473-6.

24. McConnell JF, Sparkes AH, Blunden AS, Neath PJ, Sansom J. Eosinophilic fibrosing gastritis and toxoplasmosis in a cat. J Fel Med Surg. (2007) 9:82-6. doi: 10.1016/j.jfms.2006.11.005

25. Brownlee L, Sellon RK. Diagnosis of naturally occurring toxoplasmosis by bronchoalveolar lavage in a cat. J Am Anim Hosp Assoc. (2001) 37:251-5. doi: 10.5326/15473317-37-3-251

26. Evans NA, Walker JM, Manchester AC, Bach JF. Acute respiratory distress syndrome and septic shock in a cat with disseminated toxoplasmosis. J Vet Emerg Crit Care (2017) 27:472-8. doi: 10.1111/vec.12621 
27. Simpson KE, Devine BC, Gunn-Moore D. Suspected Toxoplasmaassociated myocarditis in a cat. J Feline Med Surg. (2005) 7:203-8. doi: 10.1016/j.jfms.2004.08.004

28. Dubey JP, Prowell M. Ante-mortem diagnosis, diarrhea, oocyst shedding, treatment, isolation, and genetic typing of Toxoplasma gondii associated with clinical toxoplasmosis in a naturally infected cat. J Parasitol. (2013) 99:158-60. doi: 10.1645/GE-3257.1

29. Nordquist BC, Aronson LR. Pyogranulomatous cystitis associated with Toxoplasma gondii infection in a cat after renal transplantation. J Am Vet Med Assoc. (2008) 232:1010-2. doi: 10.2460/javma.232.7.1010

30. Gunn-Moore DA, Reed N. CNS disease in the cat: current knowledge of infectious causes. J Feline Med Surg. (2011) 13:824-36. doi: 10.1016/j.jfms.2011.09.004

31. Lindsay SA, Barrs VR, Child G, Beatty JA, Krockenberger MB. Myelitis due to reactivated spinal toxoplasmosis in a cat. J Feline Med Surg. (2010) 12:818-21. doi: 10.1016/j.jfms.2010.05.002

32. Alves L, Gorgas D, Vandevelde M, Gandini G, Henke D. Segmental meningomyelitis in 2 cats caused by Toxoplasma gondii. J Vet Intern Med. (2011) 25:148-52. doi: 10.1111/j.1939-1676.2010.0635.x

33. Mari L, Shelton GD, De Risio L. Distal polyneuropathy in an adult birman cat with toxoplasmosis. JFMS Open Rep. (2016) 2:2055116916630335. doi: $10.1177 / 2055116916630335$

34. Pfohl JC, Dewey CW. Intracranial Toxoplasma gondii granuloma in a cat. J Feline Med Surg. (2005) 7:369-74. doi: 10.1016/j.jfms.2005.03.004

35. Falzone C, Baroni M, De Lorenzi D, Mandara MT. Toxoplasma gondii brain granuloma in a cat: diagnosis using cytology from an intraoperative sample and sequential magnetic resonance imaging. J Small Anim Pract. (2008) 49:95-9. doi: 10.1111/j.1748-5827.2007.00421.x

36. Weingart C, Gruber AD, Brunnberg M, Kohn B. Hypernatremia in a cat with Toxoplasma-induced panencephalitis. J Am Anim Hosp Assoc. (2016) 52:63-7. doi: 10.5326/JAAHA-MS-6257

37. Spycher A, Geigy C, Howard J, Posthaus H, Gendron K, Gottstein B, et al. Isolation and genotyping of Toxoplasma gondii causing fatal systemic toxoplasmosis in an immunocompetent 10-year-old cat. J Vet Diagn Invest. (2011) 23:104-8. doi: 10.1177/104063871102300117

38. Jokelainen P, Simola O, Rantanen E, Näreaho A, Lohi H, Sukura A. Feline toxoplasmosis in Finland: cross-sectional epidemiological study and case series study. J Vet Diagn Invest. (2012) 24:1115-24. doi: $10.1177 / 1040638712461787$

39. Nagel SS, Williams JH, Schoeman JP. Fatal disseminated toxoplasmosis in an immunocompetent cat. J $S$ Afr Vet Assoc. (2013) 84:E1-6. doi: 10.4102/jsava.v84i1.299

40. Pena HFJ, Evangelista CM, Casagrande RA, Biezus G, Wisser CS, Ferian PE, et al. Fatal toxoplasmosis in an immunosuppressed domestic cat from Brazil caused by Toxoplasma gondii clonal type I. Rev Bras Parasitol Vet. (2017) 26:177-84. doi: 10.1590/s1984-29612017025

41. Anfray P, Bonetti C, Fabbrini F, Magnino S, Mancianti F, Abramo F. Feline cutaneous toxoplasmosis: a case report. Vet Dermatol. (2005) 16:131-6. doi: 10.1111/j.1365-3164.2005.00434.x

42. Park $\mathrm{CH}$, Ikadai $\mathrm{H}$, Yoshida E, Isomura H, Inukai H, Oyamada T. Cutaneous toxoplasmosis in a female Japanese cat. Vet Pathol. (2007) 44:683-7. doi: 10.1354/vp.44-5-683

43. Smielewska-Łoś E, Rypula K, Dzimira S. Studies on congenital toxoplasmosis in canines. Medycyna Wet. (2003) 59:141-5.

44. Taques IIGG, Barbosa TR, Martini AC, Pitchenin LC, Braga ÍA, de Melo ALT, et al. Molecular assessment of the transplacental transmission of Toxoplasma gondii, Neospora caninum, Brucella canis and Ehrlichia canis in dogs. Comp Immunol Microbiol Infect Dis. (2016) 49:47-50. doi: 10.1016/j.cimid.2016.09.002

45. Al-Qassab S, Reichel MP, Su C, Jenkins D, Hall C, Windsor PA, et al. Isolation of Toxoplasma gondii from the brain of a dog in Australia and its biological and molecular characterization. Vet Parasitol. (2009) 164:335-9. doi: 10.1016/j.vetpar.2009.05.019

46. da Silva AV, Pezerico SB, de Lima VY, d'Arc Moretti L, Pinheiro JP, Tanaka EM, et al. Genotyping of Toxoplasma gondii strains isolated from dogs with neurological signs. Vet Parasitol. (2005) 127:23-7. doi: 10.1016/j.vetpar.2004.08.020
47. Moretti Ld, Da Silva AV, Ribeiro MG, Paes AC, Langoni H. Toxoplasma gondii genotyping in a dog co-infected with distemper virus and ehrlichiosis rickettsia. Rev Inst Med Trop Sao Paulo. (2006) 48:359-63. doi: 10.1590/S0036-46652006000600012

48. Langoni H, Matteucci G, Medici B, Camossi LG, Richini-Pereira VB, Silva RC. Detection and molecular analysis of Toxoplasma gondii and Neospora caninum from dogs with neurological disorders. Rev Soc Bras Med Trop. (2012) 45:365-8. PMid: 22760137. doi: 10.1590/S0037-86822012000300016

49. da Silva RC, Caffaro K, Paula CL, Risseti RM, Langoni H, Megid J, et al. An atypical Toxoplasma gondii genotype in a rural Brazilian dog co-infected with Leishmania (Viannia) braziliensis. Rev Soc Bras Med Trop. (2015) 48:224-7. doi: 10.1590/0037-8682-0284-2014

50. Koch MO, Weiss RR, Cruz AA, Soccol VT, Gonçalves KA, Bertol M, et al. Detection and isolation of Toxoplasma gondii from fresh semen of naturally infected dogs in Southern Brazil. Reprod Domest Anim. (2016) 51:550-4. doi: $10.1111 /$ rda. 12718

51. Arantes TP, Lopes WD, Ferreira RM, Pieroni JS, Pinto VM, Sakamoto CA, et al. Toxoplasma gondii: evidence for the transmission by semen in dogs. Exp Parasitol. (2009) 123:190-4. doi: 10.1016/j.exppara.2009.07.003

52. Bresciani KD, Costa AJ, Toniollo GH, Sabatini GA, Moraes FR, Paulillo AC, et al. Experimental toxoplasmosis in pregnant bitches. Vet Parasitol. (1999) 86:143-5. doi: 10.1016/S0304-4017(99)00136-3

53. Bresciani KD, Costa AJ, Toniollo GH, Luvizzoto MC, Kanamura CT, Moraes FR, et al. Transplacental transmission of Toxoplasma gondii in reinfected pregnant female canines. Parasitol Res. (2009) 104:1213-7. doi: 10.1007/s00436-008-1317-5

54. Dubey JP, Mattixa, ME, Lipscomb TP. Lesions of neonatally induced toxoplasmosis in cats. Vet Pathol. (1996) 33:290-5. doi: 10.1177/030098589603300305

55. Atmaca HT, Dincel GC, Macun HC, Terzi OS, Uzunalioglu T, Kalender $\mathrm{H}$, et al. A rare case of feline congenital Toxoplasma gondii infection: fatal outcome of systemic toxoplasmosis for the mother and its kitten. Berl Munch Tierarztl Wochenschr. (2013) 126:216-9.

56. Sakamoto CA, da Costa AJ, Gennari SM, Pena HF, Toniollo GH, Lopes WD, et al. Experimental infection of pregnant queens with two major Brazilian clonal lineages of Toxoplasma gondii. Parasitol Res. (2009) 105:1311-6. doi: 10.1007/s00436-009-1558-y

57. Teixeira WFP, Tozato MEG, Pierucci JC, Vital GP, Cruz AC, Lopes WDZ, et al. Investigation of Toxoplasma gondii in semen, testicle and epididymis tissues of primo-infected cats (Felis catus). Vet Parasitol. (2017) 238:90-3. doi: 10.1016/j.vetpar.2017.04.003

58. Powell CC, Brewer M, Lappin MR. Detection of Toxoplasma gondii in the milk of experimentally infected lactating cats. Vet Parasitol. (2001) 102:29-33. doi: 10.1016/S0304-4017(01)00521-0

59. Dubey JP, Hoover EA. Attempted transmission of Toxoplasma gondii infection from pregnant cats to their kittens. J Am Vet Med Assoc. (1977) 170:538-40.

60. Powell CC, Lappin MR. Clinical ocular toxoplasmosis in neonatal kittens. Vet Ophthalmol. (2001) 4:87-92. doi: 10.1046/j.1463-5224.2001.00180.x

61. Sato K, Iwamoto L, Yoshiki K. Experimental toxoplasmosis in pregnant cats. J Vet Med Sci. (1993) 51005-9. doi: 10.1292/jvms.55.1005

62. Elmore SA, Jones JL, Conrad PA, Patton S, Lindsay DS, Dubey JP. Toxoplasma gondii: epidemiology, feline clinical aspects, and prevention. Trends Parasitol. (2010) 26:190-6. doi: 10.1016/j.pt.2010.01.009

63. Heidel JR, Dubey JP, Blythe LL, Walker LL, Duimstra JR, Jordan JS. Myelitis in a cat infected with Toxoplasma gondii and feline immunodeficiency virus. J Am Vet Med Assoc. (1990) 196:316-8.

64. Davidson MG, Rottman JB, English RV, Lappin MR, Tompkins MB. Feline immunodeficiency virus predisposes cats to acute generalized toxoplasmosis. Am J Pathol. (1993) 143:1486-97.

65. Dorny P, Speybroeck N, Verstraete S, Baeke M, De Becker A, Berkvens D, et al. Serological survey of Toxoplasma gondii, feline immunodeficiency virus and feline leukaemia virus in urban stray cats in Belgium. Vet Rec. (2002) 151:626-9. doi: 10.1136/vr.151.21.626

66. Kul O, Atmaca HT, Deniz A, Süer C. Clinicopathologic diagnosis of cutaneous toxoplasmosis in an angora cat. Berl Munch Tierarztl Wochenschr. (2011) 124:386-9. 
67. Last RD, Suzuki Y, Manning T, Lindsay D, Galipeau L, Whitbread TJ. A case of fatal systemic toxoplasmosis in a cat being treated with cyclosporin a for feline atopy. Vet Dermatol. (2004) 15:194-8. doi: 10.1111/j.1365-3164.2004.00371.x

68. Beatty J, Barrs V. Acute toxoplasmosis in two cats on cyclosporine therapy. Aust Vet J. (2003) 81:339. doi: 10.1111/j.1751-0813.2003.tb11508.x

69. Oliveira TS, Turchetti AP, Barbosa FBS, Bicalho ALF, Alencar CAD, Paixão TA, et al. Cutaneous toxoplasmosis in an immunosuppressed dog. Arq Bras Med Vet Zootec. (2014) 66:797-800. doi: 10.1590/1678-41626891

70. Malmasi A, Mosallanejad B, Mohebali M, Sharifian Fard M, Taheri M. Prevention of shedding and re-shedding of Toxoplasma gondii oocysts in experimentally infected cats treated with oral clindamycin: a preliminary study. Zoonoses Public Health (2009) 56:102-4. doi: 10.1111/j.1863-2378.2008.01174.x

71. Zulpo DL, Sammi AS, Dos Santos JR, Sasse JP, Martins TA, Minutti AF, et al. Toxoplasma gondii: a study of oocyst re-shedding in domestic cats. Vet Parasitol. (2018) 249:17-20. doi: 10.1016/j.vetpar.2017.10.021

72. Cong W, Meng QF, Blaga R, Villena I, Zhu XQ, Qian AD. Toxoplasma gondii, Dirofilaria immitis, feline immunodeficiency virus (FIV), and feline leukemia virus (FeLV) infections in stray and pet cats (Felis catus) in northwest China: co-infections and risk factors. Parasitol Res. (2016) 115:217-23. doi: 10.1007/s00436-015-4738-y

73. Dubey JP, Tiwari K, Chikweto A, Deallie C, Sharma R, Thomas D, et al. Isolation and RFLP genotyping of Toxoplasma gondii from the domestic dogs (Canis familiaris) from Grenada, West Indies revealed high genetic variability. Vet Parasitol. (2013) 197:623-6. doi: 10.1016/j.vetpar.2013.07.029

74. da Silva JR, Maciel BM, de Santana Souza Santos LKN, Carvalho FS, de Santana Rocha D, Lopes CWG, et al. Isolation and genotyping of Toxoplasma gondii in Brazilian dogs. Korean J Parasitol. (2017) 55:239-46. doi: $10.3347 / \mathrm{kjp} .2017 .55 .3 .239$

75. Rico-Torres CP, Del Viento-Camacho A, Caballero-Ortega H, Besné-Mérida A, Luna-Pastén H, Correa D, et al. First isolation of Toxoplasma gondii from cats of Colima, Mexico: tissue distribution and genetic characterization. Vet Parasitol. (2015) 209:125-8. doi: 10.1016/j.vetpar.2015.02.004

76. Shwab EK, Saraf P, Zhu XQ, Zhou DH, McFerrin BM, Ajzenberg D, et al. Human impact on the diversity and virulence of the ubiquitous zoonotic parasite Toxoplasma gondii. Proc Natl Acad Sci USA. (2018) 11E6956-63. doi: 10.1073/pnas.1722202115

77. Dubey JP, Chapman JL, Rosenthal BM, Mense M, Schueler RL. Clinical Sarcocystis neurona, Sarcocystis canis, Toxoplasma gondii, and Neospora caninum infections in dogs. Vet Parasitol. (2006) 137:36-49. doi: 10.1016/j.vetpar.2005.12.017

78. Dubey JP, Calero-Bernal R, Rosenthal BM, Speer CA, Fayer R. Sarcocystosis of Animals and Humans. Boca Raton, FL: CRC Press (2016).

79. Hoon-Hanks LL, Regan D, Dubey JP, Carol Porter M, Duncan CG. Hepatic neosporosis in a dog treated for pemphigus foliaceus. J Vet Diagn Invest. (2013) 25:807-10. doi: 10.1177/1040638713507257

80. Magaña A, Sánchez F, Villa K, Rivera L, Morales E. Systemic neosporosis in a dog treated for immune-mediated thrombocytopenia and hemolytic anemia. Vet Clin Pathol. (2015) 44:592-6. doi: 10.1111/vcp.12287

81. Dubey JP, Metzger FL, Hattel, AL, Lindsay DS, Fritz, DL. Canine cutaneous neosporosis: clinical improvement with clincamycin. Vet Dermatol. (1995) 6:37-43. doi: 10.1111/j.1365-3164.1995.tb00039.x

82. Dubey JP, Pimenta AL, Abboud LC, Ravasani RR, Mense M. Dermatitis in a dog associated with an unidentified Toxoplasma gondii-like parasite. Vet Parasitol. (2003) 116:51-9. doi: 10.1016/S0304-4017(03)00240-1

83. Little L, Shokek A, Dubey JP, Deheer HL. Toxoplasma gondii-like organisms in skin aspirates from a cat with disseminated protozoal infection. Vet Clin Pathol. (2005) 34:156-60. doi: 10.1111/j.1939-165X.2005.tb00030.x

84. Dubey JP, Black SS, Verma SK, Calero-Bernal R, Morris E, Hanson MA, et al. Sarcocystis neurona schizonts-associated encephalitis, chorioretinitis, and myositis in a two-month-old dog simulating toxoplasmosis, and presence of mature sarcocysts in muscles. Vet Parasitol. (2014) 202:194-200. doi: 10.1016/j.vetpar.2014.02.055

85. Prandini da Costa Reis R, Crisman R, Roser M, Malik R, Šlapeta J. Neonatal neosporosis in a 2 -week-old Bernese mountain dog infected with multiple Neospora caninum strains based on MS10 microsatellite analysis. Vet Parasitol. (2016) 221:134-8. doi: 10.1016/j.vetpar.2016.03.023
86. Berrocal A, López A. Pulmonary sarcocystosis in a puppy with canine distemper in Costa Rica. J Vet Diagn Invest. (2003) 15:292-4. doi: 10.1177/104063870301500314

87. Hawley MM, Johnson LR, Traversa D, Bucy D, Vernau KM, Vernau W. Respiratory distress associated with lungworm infection in a kitten. JFMS Open Rep. (2016) 2:2055116916675801. doi: 10.1177/20551169166 75801

88. Irvine KL, Walker JM, Friedrichs KR. Sarcocystid organisms found in bile from a dog with acute hepatitis: a case report and review of intestinal and hepatobiliary sarcocystidae infections in dogs and cats. Vet Clin Pathol. (2016) 45:57-65. doi: 10.1111/vcp.12330

89. Dubey JP, Sykes JE, Shelton GD, Sharp N, Verma SK, Calero-Bernal R, et al. Sarcocystis caninum and Sarcocystis svanai n. spp. (Apicomplexa: Sarcocystidae) associated with severe myositis and hepatitis in the domestic dog (Canis familiaris). J Eukaryot Microbiol (2015) 62:307-17. doi: $10.1111 /$ jeu. 12182

90. Lichtensteiger CA, Heinz-Taheny K, Osborne TS, Novak RJ, Lewis BA, Firth ML. West nile virus encephalitis and myocarditis in wolf and dog. Emerg Infect Dis. (2003) 9:1303-6. doi: 10.3201/eid0910.020617

91. Meseck EK, Njaa BL, Haley NJ, Park EH, Barr SC. Use of a multiplex polymerase chain reaction to rapidly differentiate Neospora caninum from Toxoplasma gondii in an adult dog with necrotizing myocarditis and myocardial infarct. J Vet Diagn Invest. (2005) 17:565-8. doi: $10.1177 / 104063870501700607$

92. Hagner K, Jokinen TS, Lavikainen A, Sukura A. Acute fulminant necrotizing myopathy in a dog caused by co-infection with ultrastructural Sarcocystis caninum and Sarcocystis svanai-like apicomplexan protozoa. Vet Parasitol. (2018) 252:153-6. doi: 10.1016/j.vetpar.2018.02.011

93. Negrin A, Cherubini GB, Lamb C, Benigni L, Adams V, Platt S. Clinical signs, magnetic resonance imaging findings and outcome in 77 cats with vestibular disease: a retrospective study. J Feline Med Surg. (2010) 12:291-9. doi: 10.1016/j.jfms.2009.10.001

94. van der Merwe LL, Lane E. Diagnosis of cerebellar cortical degeneration in a Scottish terrier using magnetic resonance imaging. J Small Anim Pract. (2001) 42:409-12. doi: 10.1111/j.1748-5827.2001.tb02491.x

95. Bolckmans A, Gielen I, Van Soens I, Bhatti S, Poncelet L, Chiers K, et al. Necrotiserende encefalitis bij de yorkshire terriër: een retrospectieve studie (1990-2008). Vlaams Diergeneeskundig Tijdschrift. (2010) 79:452-9.

96. Andrews C, Gerdin J, Patterson J, Buckles EL, Fitzgerald SD. Eastern equine encephalitis in puppies in Michigan and New York states. J Vet Diagn Invest. (2018) 30:633-6. doi: 10.1177/10406387187 74616

97. Cooley AJ, Barr B, Rejmanek D. Sarcocystis neurona encephalitis in a dog. Vet Pathol. (2007) 44:956-61. doi: 10.1354/vp.44-6-956

98. Cardinot CB, Silva JE, Yamatogi RS, Nunes CM, Biondo AW, Vieira RF, et al. Detection of Ehrlichia canis, Babesia vogeli, and Toxoplasma gondii DNA in the brain of dogs naturally infected with Leishmania infantum. J Parasitol. (2016) 102:275-9. doi: 10.1645/15-821

99. Sakamoto KP, de Melo GD, Machado GF. T and B lymphocytes in the brains of dogs with concomitant seropositivity to three pathogenic protozoans: Leishmania chagasi, Toxoplasma gondii and Neospora caninum. BMC Res Notes. (2013) 6:226. doi: 10.1186/1756-0500-6-226

100. Plugge NF, Ferreira FM, Richartz RR, de Siqueira A, Dittrich RL. Occurrence of antibodies against Neospora caninum and/or Toxoplasma gondii in dogs with neurological signs. Rev Bras Parasitol Vet. (2011) 20:202-6. doi: 10.1590/S1984-29612011000300004

Conflict of Interest Statement: The authors declare that the research was conducted in the absence of any commercial or financial relationships that could be construed as a potential conflict of interest.

Copyright (c) 2019 Calero-Bernal and Gennari. This is an open-access article distributed under the terms of the Creative Commons Attribution License (CC BY). The use, distribution or reproduction in other forums is permitted, provided the original author(s) and the copyright owner(s) are credited and that the original publication in this journal is cited, in accordance with accepted academic practice. No use, distribution or reproduction is permitted which does not comply with these terms. 